\title{
Article \\ Comparative Analysis of Cell-Free miR-205-5p, let-7f-5p, and miR-483-5p Expression in Ovarian Cell Cultures and Plasma Samples of Patients with Ovarian Cancer
}

\author{
Éva Márton ${ }^{1}$, Alexandra Varga ${ }^{1}$, Beáta Soltész ${ }^{1}$, András Penyige $^{1,2}{ }^{(1)}$, János Lukács ${ }^{3}$, Róbert Póka ${ }^{3}$, \\ Bálint $\operatorname{Nagy}^{1}$ (D) and Melinda Szilágyi ${ }^{1, * \mathbb{D}}$
}

1 Department of Human Genetics, Faculty of Medicine, University of Debrecen, H-4032 Debrecen, Hungary; marton.eva@med.unideb.hu (É.M.); varga.alexandra@med.unideb.hu (A.V.); soltesz.beata@med.unideb.hu (B.S.); penyige@med.unideb.hu (A.P.); nagy.balint@med.unideb.hu (B.N.)

2 Faculty of Pharmacy, University of Debrecen, H-4032 Debrecen, Hungary

3 Department of Obstetrics and Gynecology, Faculty of Medicine, University of Debrecen, H-4032 Debrecen, Hungary; lukacs.janos@med.unideb.hu (J.L.); pokar@med.unideb.hu (R.P.)

* Correspondence: szilagyi.melinda@med.unideb.hu; Tel.: +36-52416531

check for updates

Citation: Márton, É.; Varga, A.; Soltész, B.; Penyige, A.; Lukács, J.; Póka, R.; Nagy, B.; Szilágyi, M. Comparative Analysis of Cell-Free miR-205-5p, let-7f-5p, and miR-483-5p Expression in Ovarian Cell Cultures and Plasma Samples of Patients with Ovarian Cancer. Appl. Sci. 2021, 11, 1735. https://doi.org/ 10.3390/app11041735

Academic Editor: Francesco Cappello Received: 25 January 2021

Accepted: 13 February 2021

Published: 16 February 2021

Publisher's Note: MDPI stays neutral with regard to jurisdictional claims in published maps and institutional affiliations.

Copyright: (c) 2021 by the authors. Licensee MDPI, Basel, Switzerland. This article is an open access article distributed under the terms and conditions of the Creative Commons Attribution (CC BY) license (https:/ / creativecommons.org/licenses/by/ $4.0 /)$.

\begin{abstract}
The term liquid biopsy reveals a non-invasive diagnostic method that might be based on the quantification of cell-free microRNAs in body fluids. However, the identification of candidates for liquid biopsy is challenging. Our aim was to compare the cell-free expression of miR-483-5p, miR-205-5p, and let-7f-5p in ovarian cell cultures and plasma samples of patients with ovarian cancer. Both the intracellular and cell-free expression of miR-205-5p and let-7f-5p proved to be higher in the Estrogen Receptor $\alpha(E R \alpha)$ expressing PEO1 cell-line than in the estrogen non-sensitive A2780. Moreover, the expression of let-7f-5p was up-regulated in response to estradiol exposure that was diminished after the addition of an ER $\alpha$ selective antagonist. MiR-483-5p had lower intracellular and cell-free expression in PEO1. All these miRNAs had detectable expression level in plasma samples, among which miR-205-5p proved to be overexpressed in the plasma samples of patients with ovarian tumors compared to healthy controls and possessed an acceptable diagnostic potential with ROC-AUC 0.683 (95\% CI 0.57-0.795). Functional annotation clustering of the target genes of miR-205-5p revealed several clusters involved in cancer development. We suggest that miR-205-5p might be a promising biomarker candidate in ovarian cancer that should be further analyzed in larger sample size.
\end{abstract}

Keywords: microRNA; liquid biopsy; ovarian cancer; miR-205; let-7f

\section{Introduction}

Liquid biopsy is a promising non-invasive diagnostic approach that is based on the quantification of biomarkers in body fluids and has several advantages over conventional tissue biopsies [1,2]. Cell-free counterparts of nucleic acids are considered to be applicable biomarker candidates for liquid biopsy. These include different types of cell-free DNA (e.g., genomic DNA or mitochondrial DNA fragments) and non-coding RNA molecules (e.g., microRNAs, circular RNAs, long non-coding RNAs) [1]. Among non-coding RNA molecules, most studies focus on miRNAs due to the following reasons: (i) they are stable; (ii) easily detectable by molecular biological methods (e.g., qPCR); and (iii) their expression showed good association with the occurrence of several diseases, including cancer. This latter is due to the fact that miRNAs affect the expression of several genes involved in cancer progression and invasion; thus, miRNAs might function as oncomirs or tumor suppressors [1-4].

Among women, ovarian cancer is considered to be the 5th cause of cancer related death [5]. The occurrence of ovarian cancer is influenced by several factors, e.g., number 
of pregnancies, mutations (e.g., BRCA1/2) or the application of estrogen-based hormone replacement therapy that is often applied among post-menopausal women in order to prevent age-related diseases [6]. The 5-year survival rate highly depends on the time of diagnosis and proved to be $29 \%$ in the early and $93 \%$ in the advanced stages $[5,6]$. Two biomarkers are used routinely in ovarian cancer diagnosis: Human Epididymis Protein 4 (HE4) and Carbohydrate Antigen-125 (CA125) [7]. However, the application of these biomarkers has several limitations and they have not improved ovarian cancer diagnostics successfully $[7,8]$. The lack of specific diagnostic tools rises the need for additional biomarkers.

In our previous studies, we identified several cell-free miRNAs (e.g., miR-200 family members and miR-203a) as candidate biomarkers with good diagnostic parameters in ovarian cancer $[9,10]$. We also confirmed high cell-free miR-200s expression in estrogen sensitive epithelial ovarian cell cultures [11]. Here, we aimed to identify additional new miRNAs that might be used as future biomarkers in liquid biopsy. We present that miR-205$5 p$ and let-7f-5p has high intracellular and cell-free expression in estrogen sensitive ovarian cell cultures in contrast to miR-483-5p. Furthermore, miR-205-5p was overrepresented in the plasma samples of ovarian cancer patients, suggesting that this miRNA might be a promising biomarker candidate in non-invasive ovarian cancer diagnostics in the future.

\section{Materials and Methods}

\subsection{Patient Characteristics}

The total of 88 blood samples were involved in the study: 28 derived from patients with malignant ovarian tumors and 60 derived from age-matched healthy volunteers. Blood samples were collected at the Department of Obstetrics and Gynecology, Faculty of Medicine, University of Debrecen, during 2016-2017. Ovarian tumors were histopathologically characterized after surgery as: Cystadenocarcinoma papillare serosum $(\mathrm{N}=21)$, Cystadenocarcinoma serosum $(\mathrm{N}=3)$, Adenocarcinoma papillare serosum $(\mathrm{N}=2)$, and prior cancer $(\mathrm{N}=2)$. The International Federation of Gynecology and Obestrics (FIGO) classification of ovarian tumors was also carried out and the following stages were established for the patients: FIGO I. ( $\mathrm{N}=3)$, FIGO III. $(\mathrm{N}=18)$, and FIGO IV. $(\mathrm{N}=7)$. All participants were informed about the study, and they signed a consent. The study was approved by the Scientific and Research Ethics Committee of the Medical Research Council (ETT TUKEB) (No: 30231-2/2016/EKU), and the research was conducted in accordance with the Declaration of Helsinki.

\subsection{Plasma Collection and miRNA Isolation}

Blood sample collection was performed in EDTA tubes. The plasma fraction was used as a source for cell-free miRNA isolation that was separated by centrifugation. Samples were centrifuged at $2.500 \mathrm{~g}$ in the first step $\left(10 \mathrm{~min}, 4{ }^{\circ} \mathrm{C}\right)$, that was followed by centrifugation at $16.000 \mathrm{~g}\left(10 \mathrm{~min}, 4^{\circ} \mathrm{C}\right)$. Total RNA, including small non-coding RNAs, was extracted from $200 \mu \mathrm{L}$ plasma sample by the miRNeasy Serum/Plasma Kit (Qiagen, Hilden, Germany) following the instructions of the manufacturer.

\subsection{Cell Culturing Conditions}

Two human epithelial ovarian cell lines were used in the study. The PEO1 cell line was purchased from Merck (Darmstadt, Germany), while the A2780 cell line was kindly provided by Katalin Goda (Department of Biophysics and Cell Biology, Faculty of Medicine, University of Debrecen, Debrecen, Hungary). The cells were maintained in RPMI1640 (Corning, New York, NY, USA) supplemented with 10\% Fetal Bovine Serum (FBS) (Corning, New York, NY, USA), $1 \%$ L-glutamine, $100 \mu \mathrm{g} / \mathrm{mL}$ streptomycin, and $100 \mathrm{U} / \mathrm{mL}$ penicillin at $37^{\circ} \mathrm{C}, 90 \%$ humidity and $5 \% \mathrm{CO}_{2}$. When the effect of estradiol (E2) was tested, the cells were allowed to attach in culturing medium in 24-well plates; then, medium was removed to Phenol Red Free (PRF)-RPMI1640 (Corning, New York, NY, USA) supplemented with $5 \%$ Dextran Coated Charcoal (DCC)-FBS (Corning, New York, NY, USA) in order to avoid 
the confounding effect of phenol red or the steroids present in conventional FBS. After incubation $(24 \mathrm{~h})$, the cells were treated with $10 \mathrm{nM} \mathrm{E2}$, and miRNA was isolated $24 \mathrm{~h}$ after the treatment. In some experiments, $1 \mathrm{nM}$ methyl-piperidino-pyrazole (MPP) was also added to the cultures.

When the intracellular expression of miRNAs was studied, total RNA, including small non-coding RNAs, were isolated by the miRNeasy Kit (Qiagen, Hilden, Germany) from the cell lysates according to the manufacturer's instructions. When cell-free miRNAs secreted by the cell cultures were studied, the supernatant of cultures was used as a source for miRNA isolation using miRNeasy Serum/Plasma Kit (Qiagen, Hilden, Germany) according to the manufacturer's instructions, as previously described [11].

\subsection{MiRNA Detection}

The concentration of extracted miRNAs was determined by miRNA-specific fluorometric assay using a Qubit ${ }^{\circledR}$ 2.0 Fluorometer (Thermo Fischer Scientific, Walthman, MA, USA). Mature miRNAs were reverse transcribed by the miScript II RT Kit (Qiagen, Hilden, Germany). The expression of miR-483-5p, miR-205-5p, and let-7f-5p was determined by the miScript SYBR Green PCR Kit (Qiagen, Hilden, Germany) using miRNA specific miScript primer Assays (Qiagen, Hilden, Germany) as previously described [9,11]. MiR-103-3p was used as a housekeeping miRNA that proved to be an applicable reference in our previous studies [9-11]. Relative expression level was determined relative to miR-103-3p expression, where the relative expression level of a specific miRNA is equivalent with $2^{-\Delta \mathrm{Ct}}$.

\subsection{Bioinformatic Analysis}

Experimentally validated target genes of miR-483-5p, miR-205-5p, and let-7f-5p were identified by the miRTargetLink target prediction tool [12]. The Functional Annotation Clustering option of the Database for Annotation, Visualization and Integrated Discovery (DAVID) tool was used for functional genomic annotation of the identified miRNA target genes applying the medium stringency option [13]. We used the annotation term $p$-values and enrichment scores in order to rank the significance of the generated Functional Annotation Clusters.

\section{Results}

3.1. The Basal Expression of miR-205-5p and let-7f-5p Is Higher in the Estrogen Sensitive PEO1 Cell Line Than in the Estrogen Non-Sensitive A2780

In the beginning of our work, the basal expression level of miR-483-5p, miR-205-5p, and let-7f-5p was determined in epithelial ovarian cell lines. We applied two cell lines that differed in the expression of Estrogen Receptor $\alpha(E R \alpha)$; that receptor highly determined the expression of miRNAs in our previous studies [11]. The PEO1 highly expresses the Estrogen Receptor $\alpha(\mathrm{ER} \alpha)$ and proved to be estrogen sensitive in our previous studies [11]. The other cell line used was A2780 which does not express ER $\alpha$ and, as a result, does not respond to estrogen exposure, as it was shown previously [11]. According to our results, all three miRNAs proved to have relatively low basal expression in the A2780 cell line (Figure 1A). In case of the PEO1 cell line, miR-483-5p had similarly low relative expression level as in A2780 cells. However, the basal expression of miR-205-5p and let-7f-5p were significantly higher in PEO1 than in A2780 (Figure 1A).

The cell-free expression of these miRNAs was also determined. In these experiments, the supernatant of cell cultures was used as a source for miRNA isolation. All the tested miRNAs had detectable expression in the supernatant of the cultures. The cell-free expression level of miR-483-5p, miR-205-5p, and let-7f-5p proved to be similar to what was measured intracellularly in A2780, where all tested miRNAs showed low relative expression levels (Figure 1B). Similarly, as intracellularly, the cell-free expression level of miR-483-5p was found to be lower than miR-205-5p and let-7f-5p in the PEO1 cell line (Figure 1B). As it is shown in Figure 1B, the cell-free expression of all three miRNAs proved to be higher in PEO1 than in A2780. 
A

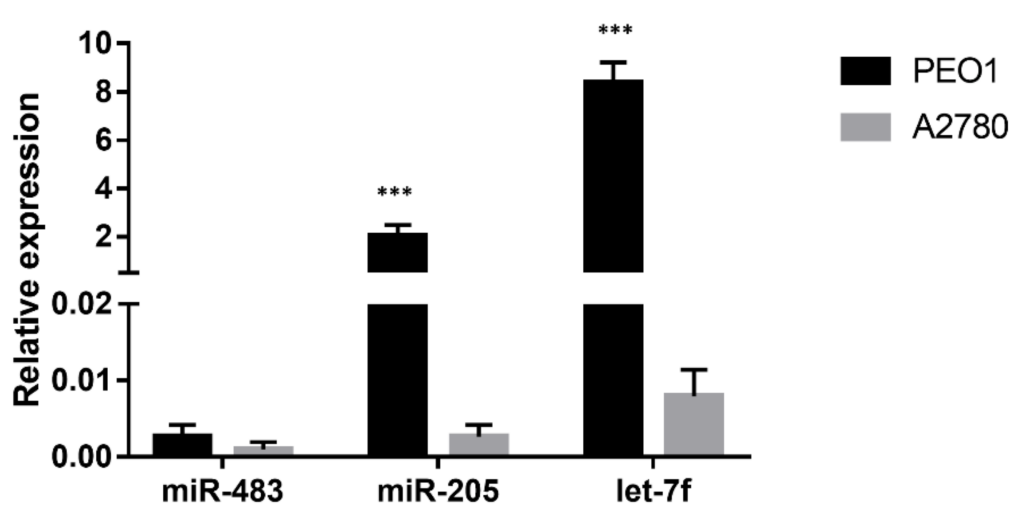

B

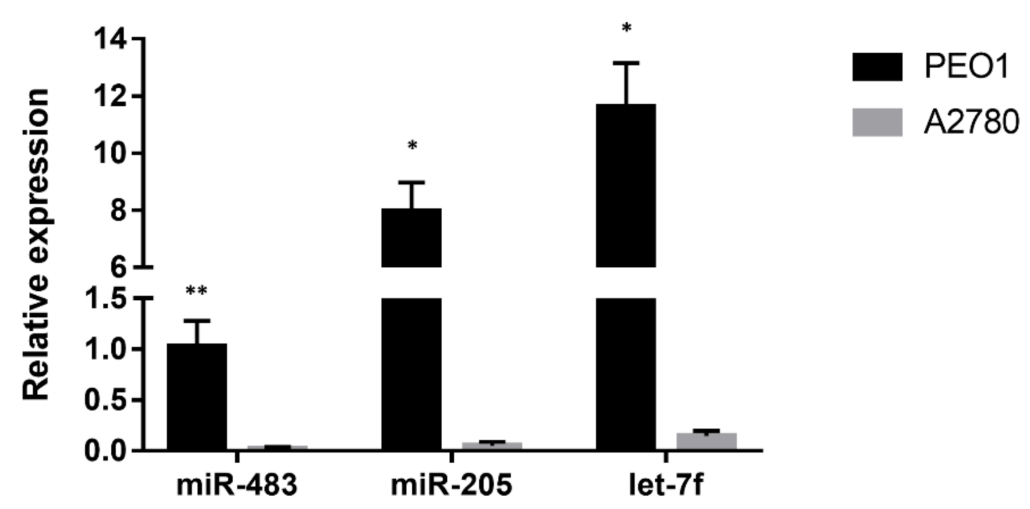

Figure 1. Basal expression levels of miR-483-5p, miR-205-5p, and let-7f-5p in the PEO1 and A2780 cell lines. (A) Intracellular miRNA expression: miRNA expression was detected in the cell lysates. (B) Cell-free miRNA expression: miRNAs were isolated from the supernatant of the cultures. Data are presented as mean \pm S.D. Significance was determined by Student's $t$-test between the $\Delta C T$ values of the PEO1 and A2780 cell lines: ${ }^{*} p<0.05 ;{ }^{* *} p<0.01 ;{ }^{* * *} p<0.001$.

\subsection{Let-7f-5p Is Upregulated in Response to Estradiol Exposure in PEO1}

The differential expression of miR-205-5p and let-7f-5p in the estrogen sensitive PEO1 and non-sensitive A2780 cell lines suggests their involvement in estrogen response. In order to prove this hypothesis, we assessed the intracellular and cell-free expression of miR-483-5p, miR-205-5p, and let-7f-5p in response to E2 exposure in the PEO1 cell line. In these experiments, cells were treated with E2 in $10 \mathrm{nM}$ concentration that proved to induce cell proliferation and migration in our previous studies [11]. According to Figure 2, the expression of let-7f-5p was upregulated in response to E2. However, no significant difference was observed in response to E2 exposure in the case of the miR-483-5p and miR-205-5p expression (Figure 2).

The role of ER $\alpha$ in the regulation of let-7f-5p and miR-205-5p expression was further studied by the application of MPP that is considered to be an ER $\alpha$ selective antagonist [14]. In these experiments $1 \mathrm{nM}$ MPP was applied together with $10 \mathrm{nM}$ E2 in the PEO1 cultures. As a result, the inductive effect of E2 was abolished in the case of the let-7f-5p expression (Figure 2). It is also important to mention that the application of MPP did not alter the expression of miR-205-5p nor miR-483-5p (Figure 2). 
$\operatorname{miR}-483$

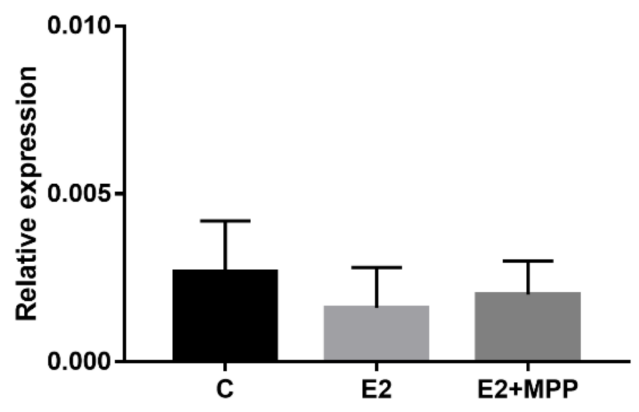

miR-205

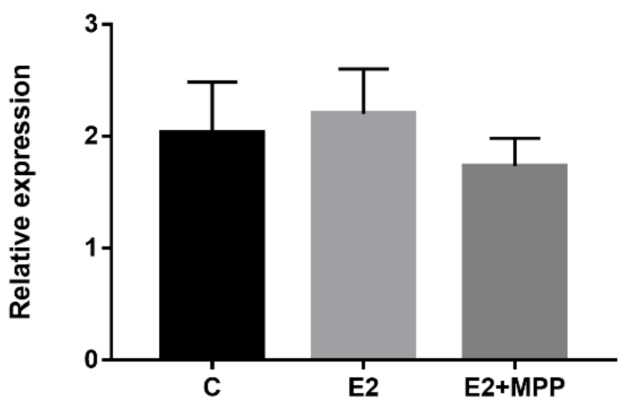

let-7f

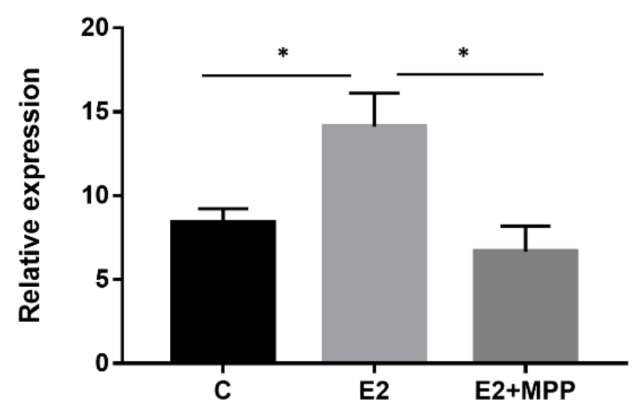

Figure 2. Relative expression levels of miR-483-5p, miR-205-5p, and let-7f-5p after the exposure to E2 and/or methyl-piperidino-pyrazole (MPP) in the PEO1 cell line. Relative expression was determined in the non-treated control (C) and E2-treated (E2) cells, as well as in those cells that were treated with MPP, together with E2 (E2 + MPP). Significance was determined by Student's $t$-test between the $\Delta C T$ values of the samples: ${ }^{*} p<0.05$.

\subsection{MiR-205-5p Is Overrepresented in the Plasma Samples of Patients with Malignant Ovarian Tumors}

We also performed a pilot study, where the applicability of miR-483-5p, miR-205-5p, and let-7f-5p was tested as biomarker candidates in the non-invasive diagnostics of ovarian cancer. In these experiments, the cell-free expression of miR-483-5p, miR-205-5p, and let-7f-5p was compared in the plasma samples of patients suffered from ovarian cancer $(\mathrm{N}=28)$ with aged-matched healthy volunteers $(\mathrm{N}=60)$. All the 3 tested miRNAs showed detectable expression in the plasma samples of both patients and healthy individuals (Figure 3). Statistical significance between the healthy and malignant samples was tested by the Mann-Whitney U test. MiR-205-5p was significantly overexpressed in the plasma samples of patients with malignant ovarian tumor $(p<0.01)$ (Figure 3). However, no significant difference was observed in the expression of miR-483-5p $(p=0.17)$ and let-7f-5p $(p=0.877)$ between the healthy and malignant samples (Figure 3$)$. In order to further 
evaluate the diagnostic potential of miR-205-5p in ovarian cancer, the Receiver Operating Characteristic-Area Under Curce (ROC-AUC) value was determined and was found to be 0.683 (95\% CI 0.57-0.795) (Figure 3).

$\operatorname{miR}-483$

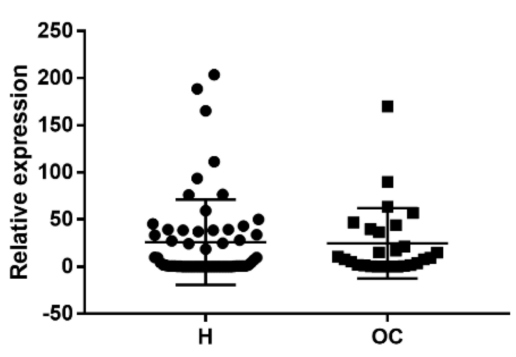

miR-205

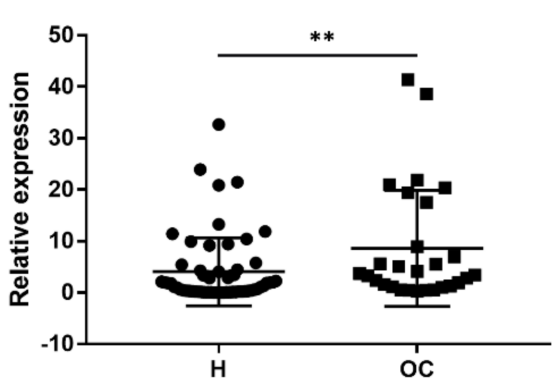

let-7f

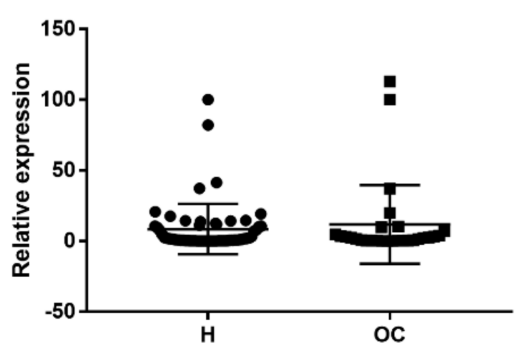

ROC curve: miR-205

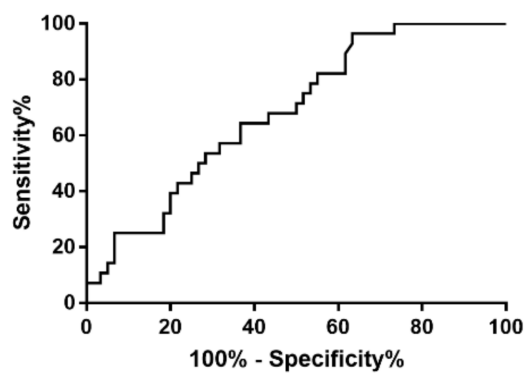

Figure 3. Scatter plot of miR-483-5p, miR-205-5p, and let-7f-5p expression in the plasma samples of patients suffered from ovarian cancer $(\mathrm{OC})$ and in healthy controls $(\mathrm{H})$. Significance was determined by Mann-Whitney $U$ test between the $\Delta \mathrm{CT}$ values of healthy and malignant samples; ${ }^{* *} p<0.01$.

\subsection{Bioinformatic Analysis of miR-483-5p, miR-205-5p, and let-7f-5p Target Genes}

We also carried out data-mining to analyze the significance of these miRNAs in the development of cancer. In the first step, the functional annotation of the target genes of miR-483-5p, let-7f-5p, and miR-205-5p was studied using the MiRtargetLink database. According to the result, miR-483-5p targets only 4 genes, in contrast to let-7f-5p and miR205-5p that have 17 and 37 target genes, respectively. Both the low basal expression level of miR-483-5p and the low number of targets suggest lower biological relevance for this miRNA compared to let-7f-5p and miR-205-5p in ovarian cells. We applied functional annotation clustering option of the DAVID annotation tool using the target genes of the three miRNAs. No functional clusters were found using the targets of miR-483-5p. The targets of let-7f-5p and miR-205-5p were clustered according to the Genetic Association Database-Disease (GAD_DISEASE), Gene Ontology-Biological Process (GOTERM_BP), and Kyoto Encyclopedia of Genes and Genomes-Pathway (KEGG_PATHWAY) databases. According to the GAD_DISEASE database, the targets of let-7f-5p and miR-205-5p are involved in the development of several cancer types, including ovarian cancer (Table 1). It is important to mention that the targets of miR-205-5p might be involved in the development of more cancer types than the targets of let-7f-5p (Table 1). According to the GOTERM_BP database, miR-205-5p might be involved in the regulation of several processes linked to the regulation of cell proliferation or migration, and let-7f-5p might be important in the regulation of DNA repair processes (Table 1). The significance of miR-205-5p in the pathways linked to cancer development is also suggested by the KEGG_PATHWAY database (Table 1). 
Table 1. Functional annotation clustering of let-7f-5p and miR-205-5p targets.

\begin{tabular}{|c|c|c|c|c|c|}
\hline \multicolumn{3}{|l|}{ let7f } & \multicolumn{3}{|l|}{ miR205 } \\
\hline \multicolumn{6}{|c|}{ GAD DISEASE } \\
\hline Category & Count & $p$-value & Category & Count & $p$-value \\
\hline prostate cancer ES: 2.59 & 5 & $6.25 \times 10^{-4}$ & prostate cancer ES: 2.94 & 6 & 0.011 \\
\hline ovarian cancer ES: 2.59 & 4 & 0.003 & breast cancer ES: 2.37 & 10 & $6.72 \times 10^{-6}$ \\
\hline epithelial ovarian cancer ES: 2.59 & 3 & 0.008 & endometrial cancer ES: 1.91 & 4 & $2.36 \times 10^{-4}$ \\
\hline \multirow[t]{5}{*}{ esophageal adenocarcinoma ES: 1.41} & 3 & 0.034 & esophageal adenocarcinoma ES: 1.91 & 7 & $3.14 \times 10^{-4}$ \\
\hline & & & epithelial ovarian cancer ES: 1.91 & 5 & 0.001 \\
\hline & & & lung cancer ES: 1.91 & 7 & 0.002 \\
\hline & & & leukemia ES: 1.91 & 3 & 0.005 \\
\hline & & & colorectal CancerES: 1.91 & 5 & 0.026 \\
\hline \multicolumn{6}{|c|}{ GOTERM Biological process } \\
\hline Category & Count & $p$-value & Category & Count & $p$-value \\
\hline \multirow[t]{5}{*}{$\begin{array}{c}\text { GO:0000715 nucleotide-excision repair, DNA } \\
\text { damage recognitionES: } 3.98\end{array}$} & 3 & $1.62 \times 10^{-4}$ & $\begin{array}{l}\text { GO:0008285 negative regulation of cell } \\
\text { proliferation ES: } 3.73\end{array}$ & 9 & $1.51 \times 10^{-6}$ \\
\hline & & & $\begin{array}{l}\text { GO:0043066 negative regulation of apoptotic } \\
\text { processES: } 2.93\end{array}$ & 6 & 0.002 \\
\hline & & & $\begin{array}{c}\text { GO:0042127 regulation of cell proliferationES: } \\
1.92\end{array}$ & 4 & 0.007 \\
\hline & & & $\begin{array}{l}\text { GO:0008284 positive regulation of cell } \\
\text { proliferationES: } 1.91\end{array}$ & 6 & 0.003 \\
\hline & & & $\begin{array}{c}\text { GO:0030336 negative regulation of cell } \\
\text { migrationES: } 1.76\end{array}$ & 3 & 0.002 \\
\hline \multicolumn{6}{|c|}{ KEGG Pathway } \\
\hline \multirow[t]{5}{*}{ Category } & Count & $p$-value & Category & Count & $p$-value \\
\hline & & & hsa05215:Prostate cancer ES: 2.83 & 5 & $5.32 \times 10^{-4}$ \\
\hline & & & hsa05222:Small cell lung cancer ES: 2.83 & 4 & 0.006 \\
\hline & & & hsa05200:Pathways in cancer ES: 2.37 & 9 & $2.03 \times 10^{-4}$ \\
\hline & & & hsa05215:Prostate cancer ES: 1.91 & 5 & $5.32 \times 10^{-4}$ \\
\hline
\end{tabular}

ES: Enrichment score.

\section{Discussion}

MiRNAs are small non-coding RNA molecules that are involved in the regulation of cancer development as oncomirs or tumor suppressors. Furthermore, they are considered to be good candidates for cancer diagnostics [4]. However, more than 2500 miRNAs have been identified to this date that makes searching for promising biomarker candidates difficult. Most of the studies focus on miRNA expression in body fluids or cell cultures exclusively. Here, we made a comprehensive study about the cell-free expression of three well-known miRNAs in cell cultures and plasma samples.

MiR-205 is proved to be a tumor suppressor that plays pivotal role in the regulation of cell proliferation and invasiveness of cancer and considered to be a promising therapeutic target $[15,16]$. The pivotal role of miR-205 in cancer is strongly suggested by our bioinformatic analysis that revealed several processes related to cancer. It is further supported by previous studies where the expression of miR-205 was confirmed to be altered in breast, endometrial, prostate, lung, bladder, thyroid, and colorectal cancer [16-23]. The relatively high basal expression of miR-205 in ovarian cell lines suggests its high biological relevance in ovarian tumors. It is in good agreement with the observation that the expression of miR-205 was up-regulated in ovarian tumor tissues compared to normal ovarian cells [24-28]. Furthermore, the cell-free expression of miR-205 proved to be high in ovarian cancer cell lines, as well as in the plasma samples of patients with ovarian cancer that was also described previously $[28,29]$. To the best of our knowledge, it is the first study that analyze miR-205 expression in a Central-European population. Our pilot study strengthens the notion that miR-205 might be a promising biomarker candidate in ovarian cancer that should be further analyzed in larger sample size. 
The differential expression of miR-205 in the estrogen sensitive and non-sensitive ovarian cell lines is another important aspect of our study. Similar phenomenon was reported previously in endometrial cancer where the expression of miR-205 and miR-200s proved to be associated with ER status [17]. However, miR-205 expression does not seem to be mediated by ER $\alpha$, in contrast to miR200s [11]. The role of miR-205 in estrogen response might be explained by the fact that it regulates ESSRG (Estrogen related receptor $\gamma$ ), which was confirmed in endometrial cells [30]. Furthermore, the overexpression of miR-205 resulted in higher E-cadherin level in colon cancer cells [31]. A similar phenomenon might exist in ovarian cancer cells, as well, since miR-205 expression is associated with E-cadherin expression, according to our previous studies [11].

Although the cell-free expression of let-7f-5p also proved to be high in the ovarian cell cultures, no significant difference was observed in its expression between the healthy and malignant plasma samples. A possible explanation might be that the expression of let- $7 \mathrm{f}$ is mostly down-regulated in cancer [29,32-36]. It is also important to mention that the expression of let-7f-5p proved to be ER $\alpha$ dependent in our study and was up-regulated in response to E2 exposure. These results are in good agreement with previous studies [37,38]. The role of let-7f in estrogen response, however, needs to be further characterized.

MiR-483 was found to be elevated in prostate, easophageal, nasopharyngeal, adrenocortical, oral, hepatocellular, and adrenocortical cancer [39-45]. Fewer studies are available about miR-483-5p expression in ovarian cancer, where the diagnostic parameters of this miRNA did not prove to be well enough for being a good biomarker candidate [29,46]. This miRNA is considered to be important in Polycystic Ovary Syndrome instead [47]. The expression of miR-483-5p proved to be low in both of the ovarian cell lines tested, and no significant difference was observed in the expression of miR-483-5p comparing the blood samples of patients and healthy individuals. These results are in good accordance with the bioinformatics analysis of miR-483-5p targets that did not result in any clusters related to the development of cancer. These data suggest that the otherwise well-detectable expression of miR-483-5p in plasma samples might not related to the expression of this miRNA in ovarian cells.

\section{Conclusions}

MiRNAs are considered to be applicable biomarkers for the non-invasive diagnosis of cancer; however, finding good biomarker candidates is challenging due to the following reasons: (i) the heterogeneity of tumors limits the application of tumor tissues for global miRNA monitoring; (ii) the low miRNA concentration in body fluids limits the use of nextgeneration sequencing technology in the monitoring of global cell-free miRNA expression in body fluids; and (iii) miRNAs in body fluids might derive from several different cells of the body not from tumors exclusively. We suggest that monitoring cell-free miRNA expression in cell cultures might be applied as an initial step in the search for biomarker candidates that might be further tested in body fluids.

Author Contributions: Conceptualization: M.S. and B.N.; Methodology: É.M. and A.V.; Software: A.P.; Validation: B.S., R.P. and J.L. Formal analysis: M.S. Investigation: É.M. and A.V. Resources: B.N. Data curation: A.P. Writing-original draft preparation: M.S. Writing-review and editing: B.N., A.P. and R.P. Visualization: M.S. All authors have read and agreed to the published version of the manuscript.

Funding: Supported by the ÚNKP-20-3 New National Excellence Program of the Ministry for Innovation and Technology from the source of the National Research, Development and Innovation Fund.

Institutional Review Board Statement: The study was conducted according to the guidelines of the Declaration of Helsinki and approved by the Scientific and Research Ethics Committee of the Medical Research Council (ETT TUKEB) (No: 30231-2/2016/EKU, date of approval: 31.05.2016).

Informed Consent Statement: Informed consent was obtained from all subjects involved in the study.

Conflicts of Interest: The authors declare no conflict of interest. 


\section{References}

1. Szilágyi, M.; Pös, O.; Márton, É.; Buglyó, G.; Soltész, B.; Keserú, J.; Penyige, A.; Szemes, T.; Nagy, B. Circulating Cell-Free Nucleic Acids: Main Characteristics and Clinical Application. Int. J. Mol. Sci. 2020, 21, 6827. [CrossRef] [PubMed]

2. Larrea, E.; Sole, C.; Manterola, L.; Goicoechea, I.; Armesto, M.; Arestin, M.; Caffarel, M.M.; Araujo, A.M.; Araiz, M.; Fernandez-Mercado, M.; et al. New Concepts in Cancer Biomarkers: Circulating miRNAs in Liquid Biopsies. Int. J. Mol. Sci. 2016, 17, 627. [CrossRef]

3. Hayes, J.; Peruzzi, P.P.; Lawler, S. MicroRNAs in cancer: Biomarkers, functions and therapy. Trends Mol. Med. 2014, 20,460-469. [CrossRef]

4. O'Brien, J.; Hayder, H.; Zayed, Y.; Peng, C. Overview of MicroRNA Biogenesis, Mechanisms of Actions, and Circulation. Front. Endocrinol. 2018, 9, 402. [CrossRef]

5. Siegel, R.L.; Miller, K.D.M.; Jemal, A. Cancer statistics, 2018. CA A Cancer J. Clin. 2018, 68, 7-30. [CrossRef]

6. Reid, B.M.; Permuth, J.B.; Sellers, T.A. Epidemiology of ovarian cancer: A review. Cancer Biol. Med. 2017, 14, 9. [CrossRef] [PubMed]

7. Montagnana, M.; Benati, M.; Danese, E. Circulating biomarkers in epithelial ovarian cancer diagnosis: From present to future perspective. Ann. Transl. Med. 2017, 5, 276. [CrossRef]

8. Sölétormos, G.; Duffy, M.J.; Hassan, S.O.A.; Verheijen, R.H.; Tholander, B.; Bast, R.C.; Gaarenstroom, K.N.; Sturgeon, C.M.; Bonfrer, J.M.; Petersen, P.H.; et al. Clinical use of cancer biomarkers in epithelial ovarian cancer: Updated guidelines from the European Group on Tumor Markers. Int. J. Gyn. Cancer 2016, 26, 43-51. [CrossRef]

9. Márton, É.; Lukács, J.; Penyige, A.; Janka, E.; Hegedüs, L.; Soltész, B.; Méhes, G.; Póka, R.; Nagy, B.; Szilágyi, M. Circulating epithelial-mesenchymal transition-associated miRNAs are promising biomarkers in ovarian cancer. J. Biotechnol. 2019, 297, 58-65. [CrossRef] [PubMed]

10. Penyige, A.; Márton, É.; Soltész, B.; Szilágyi-Bónizs, M.; Póka, R.; Lukács, J.; Széles, L.; Nagy, B. Circulating miRNA profiling in plasma samples of ovarian cancer patients. Int. J. Mol. Sci. 2019, 20, 4533. [CrossRef]

11. Márton, É.; Varga, A.; Széles, L.; Göczi, L.; Penyige, A.; Nagy, B.; Szilágyi, M. The Cell-Free Expression of MiR200 Family members correlates with estrogen sensitivity in human epithelial ovarian cells. Int. J. Mol. Sci. 2020, 21, 9725. [CrossRef]

12. miRTargetLink. Available online: https://ccb-web.cs.uni-saarland.de/mirtargetlink/multinet.php (accessed on 20 January 2021).

13. Huang, D.W.; Sherman, B.T.; Lempicki, R.A. Bioinformatics enrichment tools: Paths toward the comprehensive functional analysis of large gene lists. Nucleic Acids Res. 2009, 37, 1-13. [CrossRef]

14. Sun, J.; Huang, Y.R.; Harrington, W.R.; Sheng, S.; Katzenellenbogen, J.A.; Katzenellenbogen, B.S. Antagonists selective for estrogen receptor $\alpha$. Endocrinology 2002, 143, 941-947. [CrossRef] [PubMed]

15. Qin, A.-Y.; Zhang, X.-W.; Liu, L.; Yu, J.-P.; Li, H.; Wang, S.-Z.E.; Ren, X.-B.; Cao, S. MiR-205 in cancer: An angel or a devil? Eur. J. Cell Biol. 2013, 92, 54-60. [CrossRef] [PubMed]

16. Chauhan, N.; Dhasmana, A.; Jaggi, M.; Chauhan, S.C.; Yallapu, M.M. miR-205: A Potential biomedicine for cancer therapy. Cells 2020, 9, 1957. [CrossRef]

17. Dong, Y.; Si, J.-W.; Li, W.-T.; Liang, L.; Zhao, J.; Zhou, M.; Li, N.; Li, T. miR-200a/miR-141 and miR-205 upregulation might be associated with hormone receptor status and prognosis in endometrial carcinomas. Int. J. Clin. Exp. Pathol. 2015, 8, $2864-2875$.

18. Wu, H.; Zhu, S.; Mo, Y.-Y. Suppression of cell growth and invasion by miR-205 in breast cancer. Cell Res. 2009, 19, 439-448. [CrossRef]

19. Boll, K.; Reiche, K.; Kasack, K.; Mörbt, N.; Kretzschmar, A.K.; Tomm, J.M.; Verhaegh, J.M.; Schalken, J.; von Bergen, M.; Horn, F.; et al. MiR-130a, miR-203 and miR-205 jointly repress key oncogenic pathways and are downregulated in prostate carcinoma. Oncogene 2013, 32, 277-285. [CrossRef] [PubMed]

20. Lebanony, D.; Benjamin, H.; Gilad, S.; Ezagouri, M.; Dov, A.; Ashkenazi, K.; Gefen, N.; Izraeli, S.; Rechavi, G.; Pass, H.; et al. Diagnostic assay based on hsa-miR-205 expression distinguishes squamous from nonsquamous non-small-cell lung carcinoma. J. Clin. Oncol. 2009, 27, 2030-2037. [CrossRef]

21. Gottardo, F.; Liu, C.G.; Ferracin, M.; Calin, G.A.; Fassan, M.; Bassi, P.; Sevignani, C.; Byrne, D.; Negrini, M.; Pagano, F.; et al. Micro-RNA profiling in kidney and bladder cancers. Urol. Oncol. Semin. Orig. Investig. 2007, 25, 387-392. [CrossRef]

22. Eyking, A.; Reis, H.; Frank, M.; Gerken, G.; Schmid, K.W.; Cario, E. MiR-205 and MiR-373 are associated with aggressive human mucinous colorectal cancer. PLoS ONE 2016, 11, e0156871. [CrossRef] [PubMed]

23. Wang, X.; Zhang, H.; Jiao, K.; Zhao, C.; Liu, H.; Meng, Q.; Wang, Z.; Feng, C.; Li, Y. Effect of miR-205 on proliferation and migration of thyroid cancer cells by targeting CCNB2 and the mechanism. Oncol. Lett. 2020, 19, 2568-2574. [CrossRef]

24. Iorio, M.V.; Visone, R.; Di Leva, G.; Donati, V.; Petrocca, F.; Casalini, P.; Taccioli, C.; Volinia, S.; Liu, C.-G.; Alder, H.; et al. MicroRNA Signatures in Human Ovarian Cancer. Cancer Res. 2007, 67, 8699-8707. [CrossRef]

25. Wei, J.; Zhang, L.; Li, J.; Zhu, S.; Tai, M.; Mason, C.W.; Chapman, J.A.; Reynolds, E.A.; Weiner, C.P.; Zhou, H.H. MicroRNA-205 promotes cell invasion by repressing TCF21 in human ovarian cancer. J. Ovarian Res. 2017, 10, 33. [CrossRef]

26. Li, J.; Hu, K.; Gong, G.; Zhu, D.; Wang, Y.; Liu, H.; Wu, X. Upregulation of MiR-205 transcriptionally suppresses SMAD4 and PTEN and contributes to human ovarian cancer progression. Sci. Rep. 2017, 7, srep41330. [CrossRef] [PubMed]

27. Chu, P.; Liang, A.; Jiang, A.; Zong, L. miR-205 regulates the proliferation and invasion of ovarian cancer cells via suppressing PTEN/SMAD4 expression. Oncol. Lett. 2018, 15, 7571-7578. [CrossRef] [PubMed]

28. He, L.; Zhu, W.; Chen, Q.; Yuan, Y.; Wang, Y.; Wang, J.; Wu, X. Ovarian cancer cell-secreted exosomal miR-205 promotes metastasis by inducing angiogenesis. Theranostics 2019, 9, 8206-8220. [CrossRef] [PubMed] 
29. Zheng, H.; Zhang, L.; Zhao, Y.; Yang, D.; Song, F.; Wen, Y.; Hao, Q.; Hu, Z.; Zhang, W.; Chen, K. Plasma miRNAs as diagnostic and prognostic biomarkers for ovarian cancer. PLOS ONE 2013, 8, e77853. [CrossRef]

30. Su, N.; Qiu, H.; Chen, Y.; Yang, T.; Yan, Q.; Wan, X. miR-205 promotes tumor proliferation and invasion through targeting ESRRG in endometrial carcinoma. Oncol. Rep. 2013, 29, 2297-2302. [CrossRef]

31. Gulei, D.; Magdo, L.; Jurj, A.; Raduly, L.; Cojocneanu-Petric, R.; Moldovan, A.; Moldovan, C.; Florea, A.; Pasca, S.; Pop, L.-A.; et al. The silent healer: miR-205-5p up-regulation inhibits epithelial to mesenchymal transition in colon cancer cells by indirectly up-regulating E-cadherin expression. Cell Death Dis. 2018, 9, 1-16. [CrossRef]

32. Boyerinas, B.; Park, S.-M.; Hau, A.; E Murmann, A.; E Peter, M. The role of let-7 in cell differentiation and cancer. Endocrine-Related Cancer 2010, 17, F19-F36. [CrossRef] [PubMed]

33. Silva, J.; García, V.; Zaballos, A.; Provencio, M.; Lombardía, L.; Almonacid, L.; Garcia, J.M.; Domínguez, G.; Pena, C.; Diaz, R.; et al. Vesicle-related microRNAs in plasma of nonsmall cell lung cancer patients and correlation with survival. Eur. Respir. J. 2011, 37, 617-623. [CrossRef] [PubMed]

34. Ge, W.; Yu, D.-C.; Li, Q.-G.; Chen, X.; Zhang, C.-Y.; Ding, Y.-T. Expression of serum miR-16, let-7f, and miR-21 in patients with hepatocellular carcinoma and their clinical significances. Clin. Lab. 2014, 60, 427-434. [CrossRef] [PubMed]

35. Liang, S.; He, L.; Zhao, X.; Miao, Y.; Gu, Y.; Guo, C.; Xue, Z.; Dou, W.; Hu, F.; Wu, K.; et al. MicroRNA Let-7f Inhibits tumor invasion and metastasis by targeting MYH9 in human gastric cancer. PLoS ONE 2011, 6, e18409. [CrossRef]

36. Chirshev, E.; Oberg, K.C.; Ioffe, Y.J.; Unternaehrer, J.J. Let-7as biomarker, prognostic indicator, and therapy for precision medicine in cancer. Clin. Transl. Med. 2019, 8, 24. [CrossRef]

37. Bhat-Nakshatri, P.; Wang, G.; Collins, N.R.; Thomson, M.J.; Geistlinger, T.R.; Carroll, J.S.; Brown, M.; Hammond, S.; Srour, E.F.; Liu, Y.; et al. Estradiol-regulated microRNAs control estradiol response in breast cancer cells. Nucleic Acids Res. 2009, 37, 4850-4861. [CrossRef]

38. Fiorillo, A.A.; Heier, C.R.; Huang, Y.-F.; Tully, C.B.; Punga, T.; Punga, A.R. Estrogen Receptor, Inflammatory, and FOXO Transcription Factors Regulate Expression of Myasthenia Gravis-Associated Circulating microRNAs. Front. Immunol. 2020, 11, 151. [CrossRef]

39. Yang, Z.-G.; Ma, X.-D.; He, Z.-H.; Guo, Y.-X. miR-483-5p promotes prostate cancer cell proliferation and invasion by targeting RBM5. Int. Braz. J. Urol. 2017, 43, 1060-1067. [CrossRef]

40. Korzeniewski, N.; Tosev, G.; Pahernik, S.; Hadaschik, B.; Hohenfellner, M.; Duensing, S. Identification of cell-free microRNAs in the urine of patients with prostate cancer. Urol. Oncol. 2015, 33, 16.e17-16.e22. [CrossRef]

41. Xue, L.; Nan, J.; Dong, L.; Zhang, C.; Li, H.; Na, R.; He, H.; Wang, Y. Upregulated miR-483-5p expression as a prognostic biomarker for esophageal squamous cell carcinoma. Cancer Biomarkers 2017, 19, 193-197. [CrossRef]

42. Chabre, O.; Libé, R.; Assie, G.; Barreau, O.; Bertherat, J.; Bertagna, X.; Feige, J.-J.; Cherradi, N. Serum miR-483-5p and miR-195 are predictive of recurrence risk in adrenocortical cancer patients. Endocrine-Related Cancer 2013, 20, 579-594. [CrossRef] [PubMed]

43. Xu, H.; Yang, Y.; Zhao, H.; Yang, X.; Luo, Y.; Ren, Y.; Liu, W.; Li, N. Serum miR-483-5p: A novel diagnostic and prognostic biomarker for patients with oral squamous cell carcinoma. Tumor Biol. 2016, 37, 447-453. [CrossRef] [PubMed]

44. Shen, J.; Wang, A.; Wang, Q.; Gurvich, I.; Siegel, A.B.; Remotti, H.; Santella, R.M. Exploration of Genome-Wide Circulating MicroRNA in Hepatocellular Carcinoma: MiR-483-5p as a Potential Biomarker. Cancer Epidemiol. Biomarkers Prev. 2013, 22, 23642373. [CrossRef]

45. Patel, D.; Boufraqech, M.; Jain, M.; Zhang, L.; He, M.; Gesuwan, K.; Gulati, N.; Nilubol, N.; Fojo, T.; Kebebew, E. MiR-34a and miR-483-5p are candidate serum biomarkers for adrenocortical tumors. Surgery 2013, 154, 1224-1229. [CrossRef] [PubMed]

46. Yu, X.; Zhang, X.; Bi, T.; Ding, Y.; Zhao, J.; Wang, C.; Jia, T.; Han, D.; Guo, G.; Wang, B.; et al. MiRNA expression signature for potentially predicting the prognosis of ovarian serous carcinoma. Tumor Biol. 2013, 34, 3501-3508. [CrossRef]

47. Shi, L.; Liu, S.; Zhao, W.; Shi, J. miR-483-5p and miR-486-5p are down-regulated in cumulus cells of metaphase II oocytes from women with polycystic ovary syndrome. Reprod. Biomed. Online 2015, 31, 565-572. [CrossRef] [PubMed] 